\title{
BRITISH AND RUSSIAN ATTITUDE TO NATURE REFLECTED IN FICTION: COGNITIVE AND LINGUOCULTURAL ANALYSIS
}

Tamara Leontieva, Olga Filippova, Vladivostok State University of Economics and Service, tamara.leontieva@gmail.com,mimfil@mail.ru

\begin{abstract}
While there is a lot of literature describing national characters this article searched to find some new aspects to this issue. Previously, the survey of national cultures was limited by the attitude of the people to social, political, and economic questions. This research offers to study the ways people treat nature, the goal is to better understand two nations, the English and the Russians and define common and different traits in their characters. The article discusses the attitude of the English and the Russians to nature as part of their cultures. The methods employed in the research are cognitive, literary, and linguo-stylistic. The cognitive approach to the material investigated makes it possible to avoid stereotyping in order to come to an understanding in communication. Extracts from XIX-XX century English and Russian fiction were selected for literary and linguo-stylistic analysis. The analysis exposes a warm and sentimental attitude of the English to nature that is like mother to them. As for the Russian person nature induces him to think about the purport of life, about god and human destiny. The reason for the differences is explained by strong traditions in the English character and severe conditions of life in Russia.
\end{abstract}

UDC Number: 801.7, DOI: 10.12955/cbup.2013.37

Keywords: culture, national character, values, traditions

\section{Introduction}

When studying the national traits of different cultures, researchers usually restrict their observations to the following: attitude to power, love for the motherland, the organization of space, attitude to time, to private life, to wealth, the feeling of humor and some others. Culture makes it possible for every nation to realize its difference from others, uniqueness and specificity. The notion "culture" as Grand Encyclopedic dictionary (1998) explains it is a "historically defined level of human society, creativity, and abilities of a human being, expressed in types and forms of organizing the life and activity of people, in their interrelations as well as in material and spiritual values, in a narrower sense, culture is the sphere of human spiritual life." Speaking about culture and cognition one can add that culture's reality and dynamic force lie in the acting of its community members (Chang, 2005). Individual mental representations of the world create the national culture which is "self-contained and adequate" (Sperber, 1996).

The question about how representatives of different cultures perceive nature around them remains unanswered. It must be admitted though that some attempts of culturological analysis of literary works abundant with pictures of nature have been made. A cognitive study of landscape in British and 
American linguoculture is presented in the Candidate's dissertation of O.V. Gavrilenko (2010). The author of the thesis proclaimed the absence of any complex research of comprehending landscape originality objectified in the national cultures of the globe.

Contemporary Russian researcher V.P. Shestakov (2010), the author of a remarkable book "British Character and National Literature" stresses the necessity of culturological study of fiction for a deeper understanding of British mentality. Taking this idea into consideration we suppose to make our contribution to the survey of English literature; the aim of the work is to shed light on some characteristics of the British nation and to determine the attitude of English writers to their compatriots, their frame of mind and habits and ways of their everyday life. Works of fiction give additional material to the information a reader can gather from scientific and popular publications of psychologists, ethnologists, politicians, and others. Artistic literary works create a linguoculturological portrait of a nation and enable to see the common traits in people's behavior that unite all the nations. The latter may serve as a guarantee of peace and understanding in the whole world (Ter-Minasova, 2008).

\section{National characters of the English and the Russians in their attitude to nature}

The dominant trait of the English national character which distinguishes them from Russians is their "private territory" or so called "privacy". It is interesting to note that Russians do not recognize this quality of the English as a positive one; it is associated with "philistinism" and individualism (Kuzmenkova, 2005), hence it is regarded negatively in Russian milieu. But with time on and the acquisition of ever new information about the English this property is no longer considered contradictory.

As is well-known, the English are "a sentimental society" (Hill, 1992), and since the times immemorial they have treated nature with enormous love and gentleness as if it were an alive creature, they simply worship it. Nature, landscape become the place of their everyday life, an area of love as well as of quarrels and conflicts. Suffice it to say that the writers who portray their characters against the background of magnificent English landscape spare no colour to render its beauty and demonstrate all linguostylistic riches of the language. Shall we find the proof of the fact that the English are really sentimental in their attitude to the house, to the lawn in front of it and still follow the motto "My house is my castle"?

Soon after the "blossoming" Victorian epoch there emerges a writer, whose genius unveils the inner world of his literary characters on the background of nature; he stands for the human dignity of a person who is seeking for harmony with nature, intellect, and emotions. We are speaking about D.H. Lawrence, a master of detailed and penetrating psychological portraits of his characters depicted "with utmost delicacy of touch and subtlety of understanding" (Arnold \& Diakonova, 1967). A real Englishman, he created dazzling unforgettable individualities quite different from those living on the Continent. The stories and novels of D.H. Lawrence are indicative of the image of the motherland as "a fenced front garden" (Ovchinnikov, 2008).

Extracts from D.H. Lawrence's story "England, My England" (Lawrence, 1977) were randomized for analysis. The cognitive approach to the material studied that is undertaken here allows to discover a lot of new hues and shades in the English character and come to additional knowledge and conclusions about English mentality. As for the method the text is subjected to a complex of literary, linguostylistic, and culturological analysis for revealing the author's communicative intention and for 
finding answers to the questions that we consider very important. The hypothesis of this research is giving an answer to the question if one's own house ("home, sweet home"), private territory ("My house is my castle"), so-called isolation (privacy), and surrounding nature are indeed prior for the English nation.

In the story "England, My England" the author introduces the main character, young husband Egbert toiling with joy and inspiration his own piece of land: "He was working on the edge of the common, beyond the small brook that ran in the dip at the bottom of the garden, carrying the garden path in continuation from the plank bridge on to the common. He had cut the rough turf and bracken, leaving the grey, dryish soil bare."

The author draws a remarkable picture of nature, worthy of the brush of a painter, making almost a mysterious effect on the reader. The enumeration of divergent plants and flowers fills the text with fresh air and the scent of the field and forest. The reader perceives the text not only with his/her eyes but with other senses as well. Such a text can be called all-embracing, i.e. combining different arts, as together with the description of the common it depicts the picture of nature with paints (white, purple, flamy, green, red, yellow), and fills it with musical sounds of running water (the small brook that ran), and fragrant aroma (the earth amid flowers blossoming), more than that, one seems to touch the earth (shaggy wildness).

The author attracts the attention of the reader to the subtle feeling of beauty that characterizes Egbert as a real Englishman having the roots in ancient times. The hyperbole "had been a garden for a thousand years" as well as an allusion to Anglo-Saxons "as when the Saxons came" and Vikings, Egbert's eyes "had a touch of Viking in them" prove it. The repetition in the inner speech of the protagonist "So old, so old a place!" with expansion in the second part (addition of the word "place") together with an exclamatory structure of the sentence manifests a great affection of his for the land he works on, to the house, and to England so dear to him. He admires the beauty of the flowers and trees, exercises quivering with closeness to his house surrounded with flowers, feels "the spirit of the place". He appears to enjoy the same feelings as, probably, his ancient relative, a German invader might have felt owing to such unearthly beauty of meadows and fields: "He looked again, straining his keen blue eyes, that had a touch of the Viking in them, through the shadowy pine trees as through a doorway, at the green-grassed garden path rising from the shadow of alders by the log bridge up to the sunlit flowers". The style of the passage is impressionistic because the color palette is so bright and various: "Tall white and purple columbines, and the butt-end of the old Hampshire cottage that crouched near the earth amid flowers, blossoming in the bit of shaggy wildness round about." It is very important for the author to assert connection of the hero's feeling for nature with his love not only for contemporary England but also for the England of savage times: "Strange how the savage England lingers in patches: as here, amid these shaggy gorse commons, and marshy, snake infested places near the foot of the south downs. The spirit of place lingering on primeval, as when the Saxons came, so long ago."

D.H. Lawrence depicts the keenness of the character's delight with the help of reported speech " $A h$, how he had loved it!" This exclamation creates an emotional colouring which Egbert himself might express, it is his speech presented by the author, and the effect is great, it sounds convincing. The author goes on with this manner of story-telling, it reveals the peculiar traits of Egbert, his passion for life, his beloved wife, the surrounding landscape, the house where his wife Winifred was the hostess (The house was Winifred's), and the ability to be charmed with the beauty of a flower. V.V. Nabokov (1996) stressed the interest of a critical reader for the "images and magic of the style". The very fact that Egbert has an almost religious ecstasy for the loveliness of flowers (purple and white columbines, 
great oriental red poppies) and that he himself created this flamy flower garden is very important. The richness of the style is also composed of various syntactical structures of the sentences, long extended sentences may follow short ones, and the author's narration is interrupted with inserted reported speech: "Ah, how he had loved it! The green garden path, the tufts of flowers, purple and white columbines, and great oriental red poppies with their black chaps and mulleins tall and yellow, this flamy garden which had been a garden for a thousand years, scooped out in the little hollow among snake infested commons. He had made it flame with flowers, in a sun cup under its hedges and trees. So old, so old a place! And yet he had re-created it."

It should be noted that Egbert's love for "his England" never leaves him throughout the story and even at the time of approaching death, lying in the battle field, he notices the beauty around him and suffers not for his own life but for the life of twigs and flowers that perish in the flame of shooting and explosions. Without realizing the fact that death was near, in an "agony of consciousness and a consciousness of agony" (a brilliant case of chiasmus!) with a side look he notices the wonder and greatness of earth and sky, and the poor plants near him: "He only noticed a twig of holly with red berries fall like a gift on to the road below". This gaze of the dying person confirms our idea that love for nature is real part of English mentality. Thus the motto "England, My England" retains its significance.

The attitude of Russians towards nature is quite original and completely different from that of the English. True it is that some authors like N.V. Gogol, L.N. Tolstoy, M.M. Prishvin (Great Encyclopedic Dictionary, 1998), K.G. Paustovsky (Merriam Webster's Encyclopedia of Literature) whose works reveal a lyrical interest in nature, to name but a few Russian and Soviet ones, included pictures of nature in their artistic works. But they never came to generalizations about Russian love towards nature, like for instance D.H. Lawrence did by repeating the quotation "England, My England".

Talented Russian writers did not omit landscapes in their works, they did include them. But those excerpts served different (from the English writers) aims. Thus N.V. Gogol gives a wonderful picture of a dilapidated garden in his poem "Dead Souls" (1985). The main character Pavel Ivanovich Tchitchikoff approaches the house of the impoverished Russian aristocrat Pliushkin and he observes a very dismal picture of the village "Russian izbáz were all awry, and blackened even to unpicturesque degree". Pliushkin's house is a pitiful sight, to highlight its wretchedness the author endows it with epithets expressing negative connotations, and thus the windows are damaged, barricaded and darkened.

A great contrast to it is the picture of the garden that "stretched away behind the house". The description of it contains such positive characteristics as "the only fresh spot about the place", "the only picturesque feature in the desolate landscape", in this way the author emphasizes the force of nature over lazy and greedy master Pliushkin. The opposition between the adjectives "picturesque" and "desolate" emphasizes the mixture of feelings in the soul of the protagonist. The description of the garden is poeticized with a number of cognitive metaphors (Johnson and Lakoff, 1980) and personifications and similes "the crests of the trees, which had grown at their own will", "quivering domes of foliage". The dead garden is very aggressive to young plants, "The hop plants... had stifled the lilacs..., "threatened to envelop the shattered beech-tree", "unlighted depths..., looking like the dark throats of wild beasts". Words with negative evaluation like "gloom", "dark recesses", "decayed and hollow trunk" form a bright contrast to "A young maple-bough", "a sun-ray had crept, God alone knows how, suddenly rendering it fiery, transparent, and wondrously gleaming amid that thick 
darkness". In the like manner N.V. Gogol continues describing the garden that may be regarded as metaphor of Russia with its dark, full of troublesome periods and rare moments of glory and happiness. God is mentioned here in vain and somewhat frivolously; this is the inner speech of P.I. Tchitchikoff who is watching this unusual beauty. Although the text seems static there is a lot of life in it, the trees and plants reveal themselves gradually to Tchitchikoff's eyes, the author resorts to a lot of ing-forms indicative of unraveling wonders of the garden.

Another example of Russian attitude towards nature as the earth on which a person works for life is a brilliant character of Konstantin Levin from L. Tolstoy's novel “Anna Karenina” (1984). Like Egbert's house his is also surrounded with fields and forest. But Levin is constantly tormented by the question why people should make painful efforts to toil the earth if after all they will inevitably be buried. The land exists not for enjoyment, not for enchantment with its beauty but for hard, eternal labour. What was God's purport in creating the world?

He thinks about the aim of human existence, hard work and death. The answer to the hard question tormenting the aristocrat was given to him by one of his workers, "living for soul, in truth, in God's way." Levin realizes that the people working for him with all their efforts, exhausting themselves never forget the Lord, and live up to him. That was the answer to the question which pursued him all the time. The end of the passage about morally suffering landowner Konstantin Levin is very encouraging: the ideas of living in God's way "seemed to burst out though they had been locked up, and all striving towards one goal, they thronged whirling through his head, blinding him with their light".

The Russians work hard in harmony with God which makes their life on the earth justified; they regard nature as a source of existence, not of enjoyment. They do not have time or will to decorate their land with flowers. Such was the picture in tsarist Russia and later, in Communist Russia.

\section{Conclusion}

Surrounding nature represents for the English not only space for spending their free time, enjoying plants, rivers, rain, but it is also the place that awakes in them deep feelings, inspiration, joy or sadness. Nature helps an Englishman to stand apart from others thus demonstrating his/her "splendid isolation". An Englishman keeps up the traditional unity of man and nature, and he works in order to enlarge the beauty of the land around him.

The examined passages from Russian fiction show that nature for the Russians is the territory where they work for life; they have no time or possibility to surround themselves with picturesque lawns and their own gardens may become dilapidated. Our explanation is, the Russians live in severe circumstances, their living conditions and the climate enable them to work hard in order to survive.

Further culturological analysis is planned by the authors of this article to acquire new knowledge about the two nations.

\section{References}

Arnold, I. V. \& Diakonova, N. Y. (1967). Tri veka angliyskoy prozy [Three centuries of English prose]. Leningrad, Russia: Prosveshchenie.

Chang, Z. (2005). Cognitive studies in language and culture. Qingdao, China: Ocean University Press. 
Hill, R. (1992). We Europeans. Brussels, Belgium: Edition et Imprimerie. Retrieved April 8, 2013, from http://hkli.net/PDF/europeans.pdf

Gavrilenko, O. V. (2010). Kognitivnyye issledovaniya landshafta v britanskoy i amerikanskoy lingvokultur: sravnitelnyy analiz [Cognitive study of landscape in British and American linguocultures: Comparative analysis]. (Doctoral Dissertation). Vladivostok, Russia: Far Easten State University Press.

Gogol, N. V. (1985). Mertvyye dushi [Dead souls]. Moscow, Russia: Khudozhestvennaya literature.

Gogol, N. V. (2013, March). Dead souls. Retrieved March 14, 2013, from www.bibliomania.com/0/0/140/2404/frameset.html

Grand Encyclopedic Dictionary (2nd edition). (1998). Moscow, Russia: Grand Russian Encyclopedia.

Kuzmenkova, Y. B. (2005). Iz kulturnykh traditsiy k normam rechevogo povedeniya britantsev, amerikantsev i rossiyan [From cultural traditions to the norms of speech behaviour of the British, Americans and Russians]. Moscow, Russia: GU, HSE.

Lakoff, G. \& Johnson, M. (1980). Metaphors we live by. Chicago, IL: The University of Chicago. PMid:11661871

Lawrence, D. H. ( 1977). Odour of chrysanthemums and other stories. Moscow, Russia: Progress Publishers.

Paustovsky, K.G. (1995). Merriam Webster's Encyclopedia of Literature. Springfield, MA: Merriam Webster, Inc.

Nabokov, V. V. (1996). Lektsii po russkoy literature [Lectures on Russian literature]. Moscow, Russia: Nezavisimaya Gazeta.

Ovchinnikov, V. V. (2008). Korni duba [Oak roots]. Moscow, Russia: AST East-West Publishing House.

Shestakov, V.P. (2010). Angliyskaya literatura i angliyskiy natsionalnyy kharakter [English literature and English national character]. Saint-Petersburg, Russia: Nestor-Istoriya.

Sperber, D. (1996). Explaining culture: a naturalistic approach. Cambridge, MA: Blackwell.

Ter-Minasova, S. G. (2008). Yazyk i mezhkulturnaya kommunikatsiya [Language and cross-cultural communication]. Moscow, Russia: MSU publishers.

Tolstoy, L. N. (1984). Anna Karenina [Anna Karenina]. Moscow, Russia: Moskovsky rabochy.

Tolstoy, L. N. (2013). Anna Karenina. Retrieved March 17, 2013, from

http://www.literature.org/authors/tolstoy-leo/anna-karenina/part-08/chapter-12.html 